\title{
New Aspects of DNA-based Authentication of Chinese Medicinal Plants by Molecular Biological Techniques
}

\author{
Author \\ Günther Heubl \\ Affiliation \\ Biology Department I - Systematic Botany, Ludwig-Maximilians University Munich, \\ Munich, Germany
}

Key words

- authentication

- species identification

- Chinese medicinal plants

- standardization

- molecular markers

- DNA technologies received May 12, 2010

revised October 4, 2010

accepted October 7, 2010

Bibliography

Dol http://dx.doi.org/

10.1055/s-0030-1250519

Published online November 5 ,

2010

Planta Med 2010; 76:

1963-1974 @ Georg Thieme

Verlag KG Stuttgart · New York .

ISSN 0032-0943

\section{Correspondence}

Prof. Dr. Günther Heubl

Department Biologie I -

Systematische Botanik

LMU München

Menzingerst. 67

80638 München

Germany

Phone: +498917861207

Fax: +4989172638

heubl@|rz.uni-muenchen.de

\section{Abstract}

$\nabla$

DNA technology provides a powerful tool to complement chemical analyses for authentication of Chinese medicinal plants and to ensure that herbal materials are not contaminated with ineffective or potentially harmful substitutes or adulterants. In the last two decades molecular biotechnology has provided sophisticated molecular techniques for authentication of botanical materials at the DNA level. This review provides an account of the

\section{Introduction}

$\nabla$

China's plant diversity is exceptionally rich. The flora of China contains approximately 31500 species of vascular plants representing nearly oneeighth of the world's total plant species $[1,2]$. It is estimated that 10000 species are endemic and that more than 5000 Chinese species are used for therapy in traditional Chinese medicine $[3,4]$. Chinese medicinal herbs have been used for millennia and are becoming increasingly popular in the western world. Consequently, there is an enormous demand for medicinal plants.

A severe problem on the global market is that many erroneous substitutes and adulterants are traded due to their lower costs or misidentification of species with similar morphological features. There are several cases of Chinese herbs for which substitutes have been documented and reports that some of the adulterants or substitutes caused serious intoxications and even deaths [5-10].

Consequently, the authentication of Chinese medicinal plants depending on the correct identification of the species is an essential prerequisite to ensure safety, herbal drug quality, and therapeutic efficacy [11]. Identification of herbal materials, which commonly consist of dried or processed parts, is generally difficult. This is particularly true for several species which have the same most commonly used DNA-based technologies (RAPD, RFLP, ARMS, CAPS, AFLP, DAF, ISSR, SSR, sequencing, hybridization and microarrays) including suitable examples of Chinese medical plants. A critical evaluation of all methods is presented concerning sensitivity, reliability, reproducibility, and running costs. Recent achievements in the field of DNA barcoding and DNA chip technology that offer great potentials for screening of DNA and emerging new developments for future identification of species are briefly outlined.

name or similar looking herbal materials that can often vary remarkably in their medicinal properties [12-15]. In practice, the identification of medicinal plants relies mainly on morphological and chemical analyses. Many pharmacopoeias [1618] refer to macroscopic and microscopic evaluation (morphology, histology) and chemical profiling (TLC-, HPLC-, and GC-fingerprinting) for quality control and standardization of raw and processed herbs $[19,20]$. However, chemical variability within the plant material often hinders the confirmation of its botanical identity as the chemical composition is affected by growth and storage conditions as well as by the harvesting process. Otherwise microscopic examination of drugs requires botanical expertise for unequivocal authentication as related species often possess similar features.

With the improvements in molecular biotechnology and plant genetics in the past decades, genetic tools are considered to provide more reliability for the authentication of herbal materials at the DNA level. Thus various DNA-based molecular marker techniques are meanwhile applied in many fields and their application is remarkably increasing for species characterization in medicinal plants [21-24]. This is especially useful in case of those taxa that are frequently substituted or adulterated with other species or varieties that 
are morphologically and/or phytochemically almost indistinguishable.

Benefiting in the first place from PCR techniques, DNA markers have become a powerful tool for identification and authentication of plant and animal species [25-27]. Contrary to chemical fingerprinting which is strongly influenced by age, physiological conditions, environmental factors, cultivation area, harvesting period, drying and storage conditions, DNA is an extremely stable macromolecule that is not affected by external factors and therefore can be recovered from fresh, dried and even processed biological material. Additionally, the markers are not tissue-specific and thus can be detected at any stage of organism development. Moreover, only a small amount of sample is sufficient for analysis.

Especially DNA-barcoding (an initiative by $\mathrm{CBOL}=$ Consortium for the Barcode of Life) uses standard DNA markers from plastidal, mitochondrial, and nuclear regions to facilitate a correct taxonomic identification of species and has become a basic tool for DNA chip technology $[28,29]$.

This review provides an account on DNA-based technologies and most commonly used assays with emphasis on those based on DNA hybridization, restriction enzymes, random PCR amplifications, species-specific PCR primers, and DNA sequencing. A critical evaluation of all methods is presented focusing on their discriminatory power, sensitivity, reproducibility, user-friendliness, and costs.

\section{Types of DNA Methods and Markers Used in Plant Genome Analysis $\checkmark$}

There are various types of DNA-based molecular techniques that are used to evaluate DNA polymorphism for authentication of plant taxa $[23,24,26,27]$. These are hybridization-based methods, polymerase chain reaction (PCR)-based methods, and sequencing-based methods ( $\bullet$ Table 1 ). In recent times the use of multilocus sequence analysis (MLSA), as commonly used for phylogenetic studies, has proven its discriminatory power. Additionally, DNA microarrays that contain thousands of probes are promising new developments for sensitive and high-throughput taxon identification $[30,31]$.

\section{Non-PCR-based methods}

Hybridization-based methods (RFLP): DNA hybridization is a process in which two single stranded DNA fragments anneal into a double-stranded nucleic acid. Restriction fragment length polymorphism (RFLP) implies that a single restriction enzyme produces fragments of different lengths from the DNA marker of different strains of a species or from different related species. In a first step, genomic (or alternatively plastidal) DNA is digested with one or two selected restriction enzymes, and the fragments are separated through electrophoresis on an agarose gel. The resulting differential DNA fragment profile is then transferred to a matrix (e.g., nitrocellulose or nylon membranes) and hybridized with a chemically labelled DNA probe under conditions favoring DNA-DNA hybridization. The fragments to which the probe has hybridized are fluorescent labelled or sometimes linked with enzymes that catalyze a color reaction (digoxigenin - alkaline phosphatase) [32]. Polymorphisms are detected by the presence or absence of bands. The RFLP markers are relatively polymorphic, codominantly inherited, and highly reproducible. The method also provides an opportunity to simultaneously screen numerous samples. DNA blots can be analyzed repeatedly by stripping and reprobing with different RFLP probes. The technique is time-consuming, labor-intensive and requires a large quantity of high amounts of good quality or undegraded DNA.

RFLP combined with DNA hybridization has been mainly used for phylogenetic studies in the past, e.g., in Lupinus [33], Hedysarum [34], Triticum [35], Musa [36] and for detection of Dendrobium [37] and Fritillaria species [38].

\section{PCR-based methods}

PCR-based markers involve amplification of particular DNA loci, with the help of specific or arbitrary oligonucleotide primers and a thermostable DNA polymerase enzyme. The major advantages of PCR techniques are that mainly only a small amount of DNA is required, no prior sequence information is needed, and many genetic markers can be generated within a short time. Depending on the primers used for amplification, the PCR-based techniques can be grouped into 1) arbitrary or semi-arbitrary primed PCR techniques that need no prior sequence information (e.g., AP-PCR, DAF, RAPD, AFLP, ISSR); and 2) site-targeted PCR techniques that are developed from known DNA sequences (e.g., CAPS, SSR, SCAR, STS).

RAPD (random amplified polymorphic DNA): The RAPD technology utilizes low-stringency polymerase chain reaction (PCR) amplification with single, short, and arbitrary synthetic oligonucleotide primers (usually $10 \mathrm{bp}$ length) to generate a high number of anonymous DNA fragments. DNA polymorphism can be due to mismatches at the primer site, appearance of a new primer site, and the length of the amplified region between primer sites. Amplification products are generally separated on agarose gels and stained with ethidium bromide. Decamer primer kits are commercially available from various sources. RAPDs are inherited as dominant-recessive characters which means that homozygotes and heterozygotes cannot be distinguished. Low expense, efficiency in developing large number of DNA markers in a short time, and requirement of basic molecular equipment has made the RAPD technique valuable although band reproducibility, problems of comigration, and scoring errors are a major problem.

The technique has been applied in many plant groups such as Glycyrrhiza [42], Atractylodes [43,44], Astragalus [45], Amomun [46], Scutellaria [47], Panax [48-51], Aconitum [52], Ginkgo [53], Anectochilus [54], Lycium [55], Angelica [56], Bupleurum [57], Dendrobium [58], Magnolia [59], Asarum [60], Apocynum [61], Trollius [62], Phyllanthus [63], Indigofera [64], Coptis [65], Codonopsis [66], Taraxacum [67], Elephantopus [68], and Rehmannia [69].

$A P-P C R$ (arbitrary polymerase chain reaction): AP-PCR (or arbitrarily chosen primers ACP-PCR) is a special case of RAPD using single primers approximately $10-50$ bp in length [39]. In AP-PCR the amplification is in three parts. In the first two cycles annealing is under nonstringent conditions. Higher primer concentrations are used in the first cycle. Often primers of variable length are used, and products are mostly analyzed on polyacrylamide gels. AP-PCR has been applied in various groups for identification of species and analysis of genetic variation $[40,41]$.

DAF (DNA amplification fingerprinting): As with arbitrarily primed polymerase chain reaction (AP-PCR), DNA amplification fingerprinting (DAF) is also an independently developed methodology, which is a variant of RAPD. For PCR amplification, very short primers of 5-8 nucleotides are used that produce a very complex banding pattern $[70,71]$. DAF requires careful optimization of parameters and only two temperature cycles are required. 
Table 1 Quick overview of DNA based methods or technologies, investigated TCM plant taxa (genus), and reference.

\begin{tabular}{|c|c|c|c|}
\hline \multirow[t]{2}{*}{ DNA method } & & TCM plant & References \\
\hline & Gene & \multicolumn{2}{|l|}{ Systematic name-genus } \\
\hline \multirow{6}{*}{$\begin{array}{l}\text { Hybridization- } \\
\text { RFLP }\end{array}$} & & Lupinus & [33] \\
\hline & & Hedysarum & [34] \\
\hline & & Triticum & [35] \\
\hline & & Musa & [36] \\
\hline & & Dendrobium & [37] \\
\hline & & Fritillaria & [38] \\
\hline \multirow{24}{*}{\multicolumn{2}{|c|}{ RAPD }} & Glycyrrhiza & [42] \\
\hline & & Atractylodes & {$[43,44]$} \\
\hline & & Astragalus & [45] \\
\hline & & Amomum & [46] \\
\hline & & Scutellaria & [47] \\
\hline & & Panax & [48-51] \\
\hline & & Aconitum & [52] \\
\hline & & Ginkgo & [53] \\
\hline & & Anectochilus & [54] \\
\hline & & Lycium & [55] \\
\hline & & Angelica & [56] \\
\hline & & Bupleurum & [57] \\
\hline & & Dendrobium & [58] \\
\hline & & Magnolia & [59] \\
\hline & & Asarum & [60] \\
\hline & & Apocynum & [61] \\
\hline & & Trollius & [62] \\
\hline & & Phyllanthus & [63] \\
\hline & & Indigofera & [64] \\
\hline & & Coptis & [65] \\
\hline & & Codonopsis & [66] \\
\hline & & Taraxacum & [67] \\
\hline & & Elephantopus & [68] \\
\hline & & Rehmannia & [69] \\
\hline \multirow{8}{*}{\multicolumn{2}{|c|}{ ISSR }} & Dendrobium & [75] \\
\hline & & Cistanche & [76] \\
\hline & & Fritillaria & [77] \\
\hline & & Salvia & [78] \\
\hline & & Vitex & [79] \\
\hline & & Cannabis & [80] \\
\hline & & Rhodiola & [81] \\
\hline & & Houttunya & [82] \\
\hline \multirow{6}{*}{\multicolumn{2}{|c|}{ AFLP }} & Panax & {$[87,88]$} \\
\hline & & Actaea & [89] \\
\hline & & Plectranthus & [90] \\
\hline & & Caladium & [91] \\
\hline & & Cannabis & [92] \\
\hline & & Rehmannia & [93] \\
\hline \multirow{2}{*}{\multicolumn{2}{|c|}{ RAMPO }} & Phoenix & [95] \\
\hline & & Ficus & [96] \\
\hline \multirow[t]{14}{*}{ Sequencing } & ITS & Panax & {$[101,102]$} \\
\hline & & Asarum & [103-105] \\
\hline & & Astragalus & $\begin{array}{l}{[106,107,} \\
171]\end{array}$ \\
\hline & & Dendrobium & [108-111] \\
\hline & & Fritillaria & [112] \\
\hline & & Leonurus & [113] \\
\hline & & Perilla & {$[114]$} \\
\hline & & Rehmannia & [115] \\
\hline & & Salvia & [116] \\
\hline & & Swertia & [117] \\
\hline & & Plantago & [118] \\
\hline & & Bupleurum & [119] \\
\hline & & Euphorbia & {$[120,121]$} \\
\hline & & Hedysarum & [171] \\
\hline
\end{tabular}

Table 1 Quick overview of DNA based methods or technologies, investigated TCM plant taxa (genus), and reference. (continued)

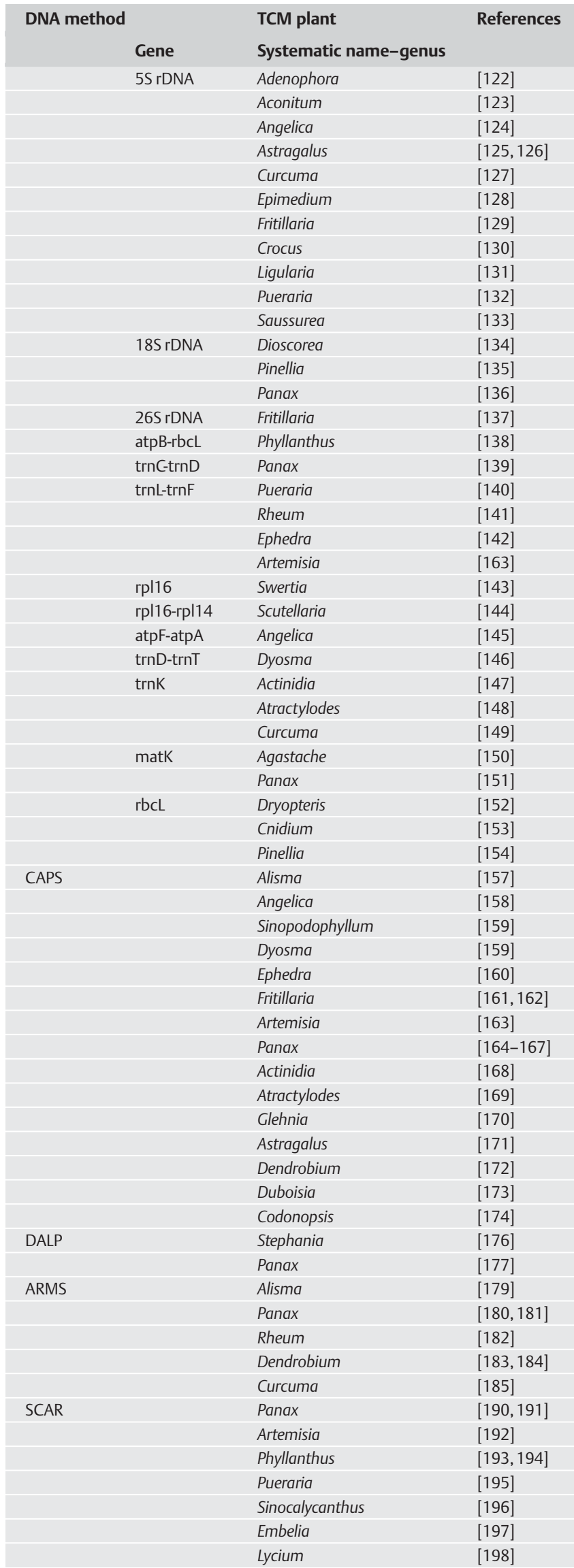


Table 1 Quick overview of DNA based methods or technologies, investigated TCM plant taxa (genus), and reference. (continued)

\begin{tabular}{|c|c|c|c|}
\hline \multirow[t]{2}{*}{ DNA method } & & TCM plant & References \\
\hline & Gene & \multicolumn{2}{|l|}{ Systematic name-genus } \\
\hline \multirow{6}{*}{\multicolumn{2}{|c|}{ SSR }} & Panax & {$[202,203]$} \\
\hline & & Acanthopanax & [204] \\
\hline & & Dendrobium & [205] \\
\hline & & Cymbopogon & [206] \\
\hline & & Bupleurum & [207] \\
\hline & & Schisandra & [208] \\
\hline \multirow{3}{*}{\multicolumn{2}{|c|}{ SAMPL }} & Cicer & [213] \\
\hline & & Lactuca & [214] \\
\hline & & Tribulus & [215] \\
\hline \multirow{5}{*}{\multicolumn{2}{|c|}{ DAMD }} & Oryza & [219] \\
\hline & & Panax & [220] \\
\hline & & Capsicum & [221] \\
\hline & & Salvia & [222] \\
\hline & & Morus & [223] \\
\hline \multirow{4}{*}{\multicolumn{2}{|c|}{ Microarrays }} & Fritillaria & {$[228]$} \\
\hline & & Dendrobium & {$[229,230]$} \\
\hline & & Bupleurum & [231] \\
\hline & & Panax & [232] \\
\hline
\end{tabular}

DAF products are routinely separated by polyacrylamide gels and detected by silver staining [72].

Although DAF and AP-PCR are different with respect to the length of the random primers, amplification conditions, and visualization methods, they all differ from the standard PCR condition in that only a single oligonucleotide of the random sequence is employed and no prior knowledge of the genome is required.

ISSR (inter-simple sequence repeat): ISSR markers are more and more in demand, because they are known to be abundant, very reproducible, highly polymorphic, informative, and quick to use $[73,74]$. Neither sequence information nor prior genetic studies are required. ISSR uses the presence throughout the genome of simple sequence repeats (SSRs) which are ubiquitous, abundant, and highly polymorphic tandem repeat motifs composed of 1 to 7 nucleotides. Inter-simple sequence repeat (ISSR) permits detection of polymorphisms in inter-microsatellite loci. The primers used can be 5' or 3' anchored by 1-3 selective nucleotides to prevent internal priming and to amplify only a subset of the targeted inter-repeat regions.

It has been used in the authentication of Dendrobium [75], Cistanche [76], Fritillaria [77], Salvia [78], Vitex [79], Cannabis [80], Rhodiola [81], and Houttuynia [82].

AFLP (amplified fragment length polymorphism): The AFLP technique is a powerful DNA fingerprinting technology applicable to any organism without the need for prior sequence knowledge. It is a multilocus approach combining restriction fragment analysis with selective PCR amplification [83,84]. In a first step, total genomic DNA is digested with two or more restriction enzymes (e.g., EcoRI; MseI) producing stick ends, and the fragments are ligated to specific adapters (oligonucleotide $10-30$ bp length). The ligated DNA fragments are then amplified twice under highly stringent conditions by PCR using radioactive or fluorescence-labelled primers complementary to the adapter and restriction site sequence. Using selective primers which include additional nucleotides at their 3' end, the complexity of the mixture of fragments can be reduced. The amplicons are separated on a polyacrylamide gel, followed by visualization of the banding pattern [85]. The AFLP technique is a reliable and robust molecular marker assay that permits the simultaneous screening of different loci randomly distributed throughout the genome [86]. It is very efficient in revealing polymorphisms even between closely related individuals. However, degraded DNA can lead to wrong banding patterns. It has been used for recognition of individuals (paternity analysis, selfing rates, identification of cultivars, clones, etc.) and studying genetic diversity of Chinese medicinal plants. AFLP-based techniques were used in Panax [87,88], Actaea [89], Plectranthus [90], Caladium [91], Cannabis [92], and Rehmannia [93].

RAMPO (random amplified microsatellite polymorphisms): This method, also termed RAHM (random amplified hybridization microsatellite) or RAMS (randomly amplified microsatellites), combines arbitrarily primed PCR (RAPD) with microsatellite hybridization to produce polymorphic genetic fingerprints [94]. No prior sequence information is needed. Genomic DNA is first amplified with a single arbitrary or microsatellite-complementary PCR primer. After electrophoretic separation and staining of the PCR products, the gel is either dried or blotted onto a nylon membrane, and subsequently hybridized to a labelled, microsatellitecomplementary oligonucleotide probe (e.g., [GT]8 or [GA]8). The method is mainly used for identification and discrimination of genotypes within and among populations, cultivates, germplasm, etc. $[95,96]$.

\section{PCR and DNA sequencing-based methods}

DNA sequencing is a powerful tool to characterize species, analyze phylogenetic relationships, population genetics, and evolutionary processes [97]. DNA polymorphisms are revealed by determining the nucleotide sequence in a defined region of the genome and aligning the sequence with homologous regions of related organisms [98].

By choosing appropriate regions of the nuclear, plastidal, or mitochondrial genome this approach provides a highly reproducible analysis at various taxonomic ranks to differentiate TCM plants from its substitutes or adulterants.

In order to provide security for a correct species identification based on DNA sequence data, it is necessary to have a herbarium specimen for verification or a reliable database that guarantees that the reference specimen was correctly identified by a taxonomic expert. Additionally, the sequence should be obtained in independent studies including related taxa. A common way to assign a particular sequence to a taxon is to perform a BLAST search (basic local alignment search tool) in the GenBank database of NCBI. However, care must be taken when assigning the questioned sequence to the species with the highest similarity, because several gaps and false sequences are known to be present in these databases.

There are many studies concerning the application of DNA sequence-based markers to differentiate medicinal taxa used in TCM from its substitutes or adulterants. The ITS region of 18S-26S rDNA has proven to be an important and useful gene locus for DNA barcoding applications $[99,100]$. Especially the ITS2 locus was revealed to discriminate among 4800 species with a probability of $92.7 \%[99,100]$.

Sequencing analyses based on this nuclear marker have been applied to Panax [101,102], Asarum [103-105], Astragalus [106, 107], Dendrobium [108-111], Fritillaria [112], Leonurus [113], Perilla [114], Phyllanthus [115], Rehmannia [116], Salvia [117], Swertia [118], Plantago [119], Bupleurum [120], and Euphorbia [121]. 
Another frequently used marker is the nuclear 5S rDNA intergenic spacer used for authentication of Adenophora [122], Aconitum [123], Angelica [124], Astragalus [125,126], Curcuma [127], Epimedium [128], Fritillaria [129], Crocus [130], Ligularia [131], Pueraria [132], and Saussurea [133].

From nuclear DNA also 18S rDNA has been tested in Dioscorea [134], Pinellia [135] and Panax [136], the 26S rDNA marker in Fritillaria [137].

From chloroplast DNA, a couple of markers including genes, intergenic spacers, or introns are applied. The atpB-rbcL region was used for differentiation of Phyllanthus [138], trnC-trnD in Panax [139], trnL-F in Pueraria [140], Rheum [141] and Ephedra [142], rpl16 in Swertia [143], rpl16-rpl14 spacer in Scutellaria [144], atpF-atpA in Angelica [145], trnD-trnT in Dyosma [146], trnK in Actinidia [147], Atractylodes [148] and Curcuma [149], matK in Agastache [150], Panax [151], rbcL in Dryopteris [152], Cnidium [153], and Pinellia [154].

CAPS or PCR-RFLP (cleaved amplified polymorphic sequence): CAPS, originally named PCR-RFLP is a combination of PCR of target DNA and subsequent digestion with a restriction enzyme $[155,156]$. CAPS markers are generated in two steps. In the first step, a defined sequence is amplified using specific primers. In the second step, the PCR product is digested with a restriction enzyme usually with a four-base recognition specifity. The digested fragments are separated on agarose gels. However, the ability of CAPS to detect DNA polymorphism is not as high as SSRs or AFLPs because nucleotide changes affecting restriction sites are essential for the detection of DNA polymorphism by CAPS. Furthermore, the development of CAPS markers is only possible where mutations disrupt or create a restriction enzyme recognition site. PCR-RFLP has been used for authentication of Alisma [157], Angelica [158], Sinopodophyllum and Dysosma [159], Ephedra [160], Fritillaria [161,162], Artemisia [163], Panax [164-167], Actinidia [168], Atractylodes [169], Glehnia [170], Astragalus [171], Dendrobium [172], Duboisia [173], and Codonopsis [174].

$D A L P$ (direct amplification of length polymorphisms): This method uses an arbitrarily primed PCR (AP-PCR) to produce genomic fingerprints and to enable sequencing of DNA polymorphisms in virtually any species [175]. For PCR higher stringency is necessary.

The uniqueness of DALP relies upon the specific design of primer pairs. It uses a selective forward primer containing a 5' core sequence of the universal M13 sequencing primer plus additional bases (usually 2-5) at the 3' end, and a common reverse M13 primer. Any of the bands generated by PCR can be excised from the gel and sequenced directly using forward or reverse primers. After sequencing the polymorphic bands among the samples, species specific primers can be designed. DALP has been used to detect polymorphisms between species [175] and to authenticate Stephania yunnanensis, [176], Panax ginseng, and Panax quinquefolius [177].

ARMS and Multiplex-ARMS (amplification refractory mutation system): ARMS, also known as allele-specific polymerase chain reaction (ASPCR) is a simple, timesaving, and effective method for detecting any mutation involving single base changes (SNPs) or small deletions. It has become a standard technique that allows the discrimination of alleles [178]. The basis of ARMS is that oligonucleotides with a mismatched 3'-residue will not function as primers in the PCR. ARMS allows amplification of test DNA only when the target allele is contained within the sample and will not amplify the nontarget allele. Following an ARMS reaction, the presence or absence of a PCR product is diagnostic for the presence or absence of the target allele. A main advantage of ARMS is that the amplification step and the authentication step are combined, in that the presence or absence of a PCR product is diagnostic for the presence or absence of the target allele. The method provides a quick screening assay that does not require any form of labelling as the amplified products are visualized simply by agarose gel electrophoresis and ethidium bromide staining. Multiplex ARMS or MARMS is a similar approach but there are several primer combinations to be optimized simultaneously, which increases the complexity of the procedure. This technique has been applied in the authentication of Alisma [179], Panax [180,181], Rheum [182], Dendrobium [183,184], and Curcuma [185].

SCAR (sequence characterized amplified region): A SCAR can be used to rapidly amplify a diagnostic nucleic acid from herbal materials using a pair of specific oligonucleotide primers designed from polymorphic RAPD [186,187] or ISSR [188] fragments.

Polymorphic regions from RAPDs or ISSR are selected among amplified fingerprints. After cloning and sequencing for the selected polymorphic regions, pairs of internal primers are designed to amplify a unique and specific sequence designed as a SCAR marker. PCR results in a positive or negative amplification in target-containing and nontarget-containing samples respectively or amplification products of different sizes in the case of closely related samples. SCARs are advantageous over RAPD markers as they detect only a single locus, their amplification is less sensitive to reaction conditions, and they can potentially be converted into codominant markers [189]. Prior sequence information (i.e., sequencing the polymorphic fragments) is required for designing the primers flanking the polymorphic region. As PCR inhibitory effects of ingredients can lead to false negative results, amplification of a control fragment using the same DNA template should be performed to ensure that the quality of sample DNA is suitable for PCR.

The SCAR technique has been used for authentication of Panax [190,191] and for discrimination of species of Artemisia [192], Phyllanthus [193, 194], Pueraria [195], Sinocalycanthus [196], Embelia [197], and Lycium [198].

Microsatellites (SSR - simple sequence repeats): Hypervariable repetitive DNA sequences such as microsatellites, minisatellites or midisatellites, and satellites can be of great value in assessing a high level of polymorphism as they are distributed throughout the genomes.

Microsatellites are also known as simple sequence repeats (SSRs), short tandem repeats (STRs), or simple sequence length polymorphisms (SSLPs) are the smallest class of simple repetitive DNA sequences $[199,200]$. They are highly polymorphic and abundant sequences that are dispersed throughout most eukaryotic genomes. These molecular markers are widely used for DNA fingerprinting, paternity testing, linkage map construction, and population genetic studies but of less importance for species identification [201]. Based on tandem repeats of short (2-6 bp) DNA sequences, these markers are highly polymorphic due to variation in the number of repeat units. The repeat length at specific SSR loci is easily assayed by PCR using primers specific to conserved regions flanking the repeat array. PCR fragments are usually separated on polyacrylamide gels in combination with fluorescent detection systems. The hypervariability and codominance of SSRs, their dispersion throughout genomes and suitability for automatization are the principle reasons for their wide utility. A major limitation of SSRs is the time and high development cost required to isolate and characterize each locus when a preexisting DNA sequence is not available. Typically, this process requires 
the construction and screening of a genomic library of size-selected DNA fragments with SSR-specific probes, followed by DNA sequencing of isolated positive clones, PCR primer synthesis, and testing.

Microsatellites have been applied in Panax [202,203], Acanthopanax [204], Dendrobium [205], Cymbopogon [206], Bupleurum [207], and Schisandra [208].

SAMPL (selective amplification of microsatellite polymorphic loci): The SAMPL technique is an SSR-based modification of the amplified fragment length polymorphism (AFLP) procedure [209], but it differs from AFLP by using primers with compound microsatellite motifs in combination with oligonucleotides complementary to the end-ligated adapters for the selective amplification step [210]. In brief, genomic DNA is digested with restriction enzymes (commonly EcoRI and MseI), and the resulting fragments are ligated to adapters that contain sticky ends to the restriction sites for the enzymes at the genome fragments, and a preamplification reaction for all ligated DNA fragments is carried out with primers annealing to the adapters. These preamplified products, adequately diluted, are then used as templates for a selective SAMPL-polymerase chain reaction (PCR) that uses the adapterprimer (EcoRI oligo-1) in combination with an end-labelled microsatellite-based 15-mer oligonucleotide [211] to amplify a group of fragments from those that were restricted, ligated, and preamplified. This multiplexing genome profiling technique has not adequately been used in plant genomics, although a few reports have already documented its potential to detect polymorphisms [212]. This method was used for analysis of genetic diversity in Cicer [213], Lactuca [214] and Tribulus [215].

DAMD (directed amplification of minisatellite-region DNA): DAMD is a DNA fingerprinting method based on amplification of the regions rich in minisatellites at relatively high stringencies by using previously found VNTR core sequences as primers [216,217]. Minisatellites, also known as variable number of tandem repeats (VNTR) or hypervariable repeats (HVR), are similar to microsatellites (SSR) except that the tandem repeat DNA sequences are longer and generally consist of $10-60$-bp motifs. Extreme variations in the tandem repeat copy number of minisatellite loci are responsible for the polymorphism observed. By using the VNTR core sequence as primers, the directed amplification of minisatellite-region DNA (DAMD) with PCR is capable of producing RAPDlike results for the identification of species [218]. It is also used to generate highly variable probes for DNA fingerprinting. This method is more reproducible than RAPD due to the longer primers used.

Recently, DAMD-PCR has been successfully applied for genotyping of wheat cultivars and rice species [219]. The method has been used for authentication of Panax [220], Capsicum [221], Salvia [222], and Morus [223].

\section{DNA-microarrays (DNA chip technology)}

DNA microarrays or genechips are a high throughput technology for simultaneous analysis of multiple genes in many taxa or samples. To apply this technique for identification and authentication of herbal material it is necessary to identify a distinct DNA sequence that is unique to each species [224]. Based on the gained DNA sequences, corresponding probes are synthesized for many samples. These immobilized DNA fragments are arranged in a regular pattern on a microarray by fixation on glass slides, silicon or nylon membranes $[225,226]$.

DNA extracted from the target sample and labelled with a specific fluorescent molecule is then hybridized to the microarray
DNA. A positive hybridization is detected and visualized with fluorescence scanning or imaging equipment. The microarray is scanned to obtain a complete hybridization pattern generated by the release of a fluorescent, chemiluminescent, or colorimetric signal associated with the binding of the probe to the target DNA. A number of terms such as DNA arrays, gene chips, and biochips are often used to describe these devices [227].

Recently this technique has been applied for the identification of various species of Fritillaria [228], Dendrobium [229,230], and Bupleurum [231]. In addition, microarray technology has also been used to authenticate Panax ginseng [232] and toxic traditional Chinese medicinal materials [233] such as Aconitum, Strychnos, and Datura.

The results demonstrated that DNA microarray based technology can provide a rapid, high-throughput tool for correct botanical identification, authentication of crude plant materials, standardization and quality control, testing simultaneously hundreds of samples [226].

\section{Future Developments}

$\nabla$

New innovative automated assays and specific tools for DNA analysis are emerging and will contribute to the next generation of technologies. These are minisequencing [234,235], nanoscale DNA sequencing [236] or microsphere-based suspension arrays [237]. Further promising developments are the nanopore technology for identification of DNA bases with very high confidence, and the arrayed primer extension reaction (APEX) which is an enzymatic genotyping method to analyze hundreds to thousands of variations in the genome simultaneously in a single multiplexed reaction $[238,239]$. Another upcoming method for large-scale multiplex analysis of nucleic acid sequences is the multiplex oligonucleotide ligation assay (OLA), which can be applied for allelic discrimination in highly polymorphic genes [240].

These techniques have a high multiplexing capacity and great potentials for genotyping and future taxon identification [241].

\section{Limitation of DNA methods}

Molecular authentication methods have several advantages which make them suitable for the identification of herbs used in TCM, as compared to macroscopic, microscopic, and phytochemical analyses. The DNA-based techniques are not affected by environmental factors, independent from the physical form of the plant material, and only a low amount of material is required.

Although DNA analysis is currently considered to be cutting-edge technology, it has certain limitations.

- The applicability of a DNA-based method depends generally on the quality and quantity of the DNA, which might be a problem for dried or processed materials. Important drug-processing conditions, for example, temperature and $\mathrm{pH}$, may lead to degradation (fragmentation) of the DNA, rendering PCR analysis impossible. However, depending on the degree of degradation of DNA some methods can still be used in processed materials. For these, it is necessary to develop very short amplicons to have a certain probability of successful application [242].

- High concentrations of secondary plant compounds (polysaccharides, tannins, essential oils, phenolics, alkaloids, etc.) may influence DNA extraction or PCR reaction. In tissues of medicinal plants, secondary compounds generally get accumulated and the problem becomes severe as the material gets older. Polysaccharide contaminations are particularly problematic as 
they can inhibit the activity of many commonly used enzymes, such as polymerases, ligases, and restriction endonucleases. Polyphenol contamination of DNA makes it resistant to restriction enzymes and interacts irreversibly with proteins and nucleic acids. Choosing the most suitable DNA extraction procedure may help to eliminate the PCR inhibitors.

- Sometimes plant materials are contaminated with endophytic fungi, which might influence DNA sequencing and can be eliminated with a plant-specific primer design.

- DNA related methods can generally not be applied when the herb is processed to an extract.

- DNA markers, such as the internal transcribed spacer (ITS) region of the 18S-5.8S-26S nuclear ribosomal cistron, sometimes show intraspecific sequence variation due to nonfunctional paralogous sequences (pseudogenes). For DNA barcoding as a practical molecular method to identify species, only orthologous DNA sequences can be used. Consequently cloning of PCR products is sometimes inevitable.

- In order to establish a marker for identification of a particular species, DNA analysis of closely related species and/or varieties and common botanical contaminants and adulterants is necessary, which is a costly and time-consuming process.

\section{Conclusion}

\section{$\nabla$}

DNA technologies are reliable and powerful tools for identification of taxa at various taxonomic levels (e.g., species, subspecies, variety, strain) as they provide consistent results irrespective of age, tissue origin, physiological conditions, environmental factors, harvest, storage, and processing of samples. With the increasing demand of high-quality herbs, also the need for DNA authentication will accelerate for ensuring the therapeutic effectiveness, a fair trade of drugs and raising consumers' confidence. However, for the modernization of TCM it is inevitable in the future to compile a comprehensive database including DNA data for all investigated medicinal taxa with reference information on nomenclature, phylogenetic relationships, macroscopic and microscopic features, chemical constituents and profiling, toxicity, and voucher specimens in herbaria or museums.

\section{References}

1 Lopez-Pujol JL, Zahng FM, Song GE. Plant biodiversity in China: richly varied, endangered, and in need of conservation. Biodivers Conserv 2006; 15: 3983-4026

2 Qian H, Ricklefs RE. A comparison of the taxonomic richness of vascular plants in China and the United States. Am Nat 1999; 154: 160-181

3 Zhong YD. Big Chinese Herb Dictionary. Shanghai Kexue Jishu Chu Ban Shi. Shanghai: Shanghai Science and Technology Publishing Co.; 1977

4 Lee HH, Itokawa H, Kozuka M. Asian herbal products: The basis for development of high-quality dietary supplements and new medicines. In: Shi J, Ho CT, Shahidi F, editors. Asian Functional Foods. Boca Raton: Pub CRC Press, Taylor \& Francis Group; 2005

5 Zhao ZZ, Hu Y, Liang ZT, Yuen PSJ, Jiang ZH, Leung KSY. Authentication is fundamental for standardization of Chinese medicines. Planta Med 2006; 72: 865-874

6 Zhao ZZ, Li TYS. Easily confused Chinese medicines in Hong Kong (English edition). Hong Kong: Chinese Medicine Merchants Association Ltd.; 2007

7 Chan TY, Critchley JA. Usage and adverse effects of Chinese herbal medicines. Hum Exp Toxicol 1996; 15: 5-12

8 Gertner E, Marshall PS, Filandrinos D, Potek AS, Smith TM. Complications resulting from the use of Chinese herbal medications containing undeclared prescription drugs. Arthritis Rheum 1995; 38: 614-617

9 But PP, Tomlinson B, Cheung KO, Yong SP, Szeto ML, Lee CK. Adulterants of herbal products can cause poisoning. Br Med J 1996; 313: 117
10 Chen J, Chen L, An Z, Shi S, Zhan Y. Non-technical causes of fakes existing in Chinese medicinal material markets. Zhongyaocai 2002; 25: 516519

11 Zhao Z, Hu Y, Liang Z, Yuen J, Jiang Z. Leung KSY. Authentication is fundamental for standardization of Chinese medicines. Planta Med 2006; 72: 865-874

12 Huang HH, Yen DHT, Wu ML, DengJF, Huang CI, Lee CH. Acute Erycibe henryi Prain (“Ting Kung Teng") poisoning. Clin Toxicol 2006; 44: 71-75

13 Sun SQ Zhou Q Liu J, Huang $H$. Study on the identification of standard and false BanXia by two-dimensional infrared correlation spectroscopy. Spectrosc Spectr Anal 2004; 24: 427-430

14 Zhang WH, Shen ZJ. Comparison on macroscopic characteristics of clinical curative effect of Banxia and Shuibanxia. J Nanjing Univ Tradit Chin Med 1995; 11: 32-33

15 Zhao ZZ, Li TYS. Hong Kong Commonly Confused Chinese Medicines. Hong Kong: Chinese Medicine Merchants Association Ltd.; 2004

16 Society of Japanese Pharmacopoeia. Japanese Pharmacopoeia (English version), 14th edition. Tokyo: Junkudo Book Shop; 2001

17 Korean Food and Drug Administration. Korean Herbal Pharmacopoeia, 8th edition. Seoul: Ministry of Health Family Welfare of South Korea; 2002

18 State Pharmacopoeia Committee. Pharmacopoeia of China (2005 edition). Beijing: Chemical lndustry Publisher; 2005

19 Siow YL, Gong Y, Au-Yeung KK, Woo CW, Choy PC. Emerging issues in traditional Chinese medicine. Can J Physiol Pharmacol 2005; 83: 321-334

20 Chan $K$. Some aspects of toxic contaminants in herbal medicines. Chemosphere 2003; 52: 1361-1371

21 Shaw PC, Ngan FN, But PPH, Wang J. Molecular markers in Chinese medicinal materials. In: Shaw PC, But PPH, editors. Authentication of Chinese medicinal material by DNA technology. Singapore: World Scientific Publishing; 2002

22 Zhang YB, Shaw PC, Sze CW, Wang ZT, Tong Y. Molecular authentication of Chinese herbal materials. J Food Drug Anal 2007; 15: 1-9

23 Sucher JN, Carles MC. Genome-based approaches to the authentication of medicinal plants. Planta Med 2008; 74: 603-623

24 Shaw PC, Wong KKL, Chan AWK, Wong WC, But PPH. Patent applications for using DNA technologies to authenticate medicinal herbal material. J Chin Med 2009; 4: 1-11

25 Yip PY, Chau CF, Mak CY, Kwan HS. DNA methods for identification of Chinese medicinal materials. J Chin Med 2007; 2: 1-19

26 Kaplan J, Chavan P, Warude D, Patwardhan B. Molecular markers in herbal drug technology. Curr Sci 2004; 87: 159-165

27 Pereira F, Carneiro J, Amorim A. Identification of species with DNAbased technology: current progress and challenges. Recent Pat DNA Gene Seq 2008; 2: 187-200

28 Ratnasingham S, Hebert PDN. BOLD: the barcode of life data system (www.barcodinglife.org). Mol Ecol Notes 2007; 7: 355-364

29 Chase MW, Salamin N, Wilkinson M, Dunwell JM, Kesanakurthi RP, Haidar $N$, Savolainen $V$. Land plants and DNA barcodes: short-term and long-term goals. Philos Trans R Soc Lond Ser B Biol Sci 2005; 360: 1889-1895

30 Trau D, Lee TM, Lao AI, Lenigk R, Hsing IM, Ip NY, Carles MC, Sucher NJ. Genotyping on a complementary metal oxide semiconductor silicon polymerase chain reaction chip with integrated DNA microarray. Anal Chem 2002; 74: 3168-3173

31 Schena M, Heller RA, Theriault TP, Konrad K, Lachenmeier E, Davis RW. Microarrays: biotechnology's discovery platform for functional genomics. Trends Biotechnol 1998; 16: 301-316

32 Lashermes P, Combes MC, Cros J. Use of non-radioactive digoxigenin-labelled DNA probes for RFLP anlyses in coffee. Techique et utilisations des marqueurs moleculaires 1994; 72: 29-31

33 Yamazaki M, Sato A, Saito K, Murakoshi I. Molecular phylogeny based on RFLP and its relation with alkaloid patterns in Lupinus plants. Biol Pharm Bull 1993; 16: 1182-1184

34 Trifi-Farah N, Marrakchi M. Hedysarum phylogeny mediated by RFLP analysis of nuclear ribosomal DNA. Genet Resour Crop Evol 2001; 48: 339-345

35 Mori N, Moriguchi T, Nakamura C. RFLP analysis of nuclear DNA for study of phylogeny and domestication of tetraploid wheat. Genes Genet Syst 1997; 72: 153-161

36 Gawel NJ, Jarret RL, Whittemore AP. Restriction fragment length polymorphism (RFLP)-based phylogenetic analysis of Musa. Theor Appl Genet 1992; 84: 286-290 
37 Li T, Wang J, Lu Z. Accurate identification of closely related Dendrobium species with multiple species-specific gDNA probes. J Biochem Biophys Methods 2005; 62: 111-123

38 Tsoi PY, Woo HS, Wong MS, Chen SL, Fong WF, Xiao PG, Yang MS. Genotyping and species identification of Fritillaria by DNA chips. Yaoxue Xuebao 2003; 38: 185-190

39 Welsh J, McClelland M. Fingerprinting genomes using PCR with arbitrary primers. Nucleic Acids Res 1990; 18: 7213-7218

40 Munthali M, Ford-Lloyd BV, Newbury HJ. The random amplification of polymorphic DNA for fingerprinting plants. PCR Methods Appl 1992; 1: $274-276$

41 Kersten T, Daniel C, König GM, Knö $\beta$ W. The potential of PCR-related methods to identify medicinal plants in herbal medicinal products. Planta Med 2007; 73: 256

42 Yamasaki M, Sato A, Shimomura K, Saito K, Murakoshi I. Genetic relationships among Glycyrrhiza plants determined by RADP and RFLP analyses. Biol Pharm Bull 1994; 17: 1529-1531

43 Kohjyouma M, Nakajima S, Namera A, Shimizu R, Mizukami H, Kohda H. Random amplified polymorphic DNA analysis and variation of essential oil components of Atractylodes plants. Biol Pharm Bull 1997; 20 : 502-506

44 Chen KT, Su YC, Lin JG, Hsin LH, Su YP, Su CH, Li SY, Cheng JH, Mao SJ. Identification of Atractylodes plants in Chinese herbs and formulations by random amplified polymorphic DNA. Acta Pharmacol Sin 2001; 22: 493-497

45 Cheng KT, Su B, Chen CT, Lin CC. RAPD analysis of Astragalus medicines marketed in Taiwan. Am J Chin Med 2000; 28: 273-278

46 Wang P, Huang F, Zhou L, Cao L, Liang S, Xu H, Liu J. Analysis of Amomun villosum species and some adulterants of Zingiberaceae by RAPD. Zhong Yao Cai 2000; 23: 71-74

47 Hosokawa K, Minami M, Kawahara K, Nakamura I, Shibata T. Discrimination among three species of medicinal Scutellaria plants using RAPD markers. Planta Med 2000; 66: 270-272

48 Cheung KS, Kwan HS, But PPH, Shaw PC. Pharmacognostical identification of American and Oriental ginseng roots by genomic fingerprinting using arbitrarily primed polymerase chain reaction (AC-PCR). J Ethnopharmacol 1994; 42: 67-69

49 Shim YH, Choi JH, Park CD, Lim CJ, Cho JH, Kim HJ. Molecular differentiation of Panax species by RAPD analysis. Arch Pharm Res 2003; 26: 601-605

50 Cui XM, Lo CK, Yip K L, Dong TT, Tsim K W. Authentication of Panax notoginseng by $5 S$-rRNA spacer domain and random amplified polymorphic DNA (RAPD) analysis. Planta Med 2003; 69: 584-586

51 Lim W, Mudge KW, Weston L. Utilization of RAPD markers to assess genetic diversity of wild populations of North American ginseng (Panax quinquefolium). Planta Med 2007; 73: 71-76

52 Cole CT, Kuchenreuther MA. Molecular markers reveal little genetic differentiation among Aconitum noveboracense and A. columbianum (Ranunculaceae) populations. Am J Bot 2001; 88: 337-347

53 Fan XX, Shen L, Zhang X, Chen XY, Fu CX. Assessing genetic diversity of Ginkgo biloba L. (Ginkgoaceae) populations from China by RAPD markers. Biochem Genet 2004; 42: 269-278

54 Cheng KT, Fu LC, Wang CS, Hsu FL, Tsay HS. Identification of Anoectochilus formosanus and Anoectochilus koshunensis species with RAPD markers. Planta Med 1998; 64: 46-49

55 Zhang KYB, Leung HW, Yeung HW, Wong RNS. Differentiation of Lycium barbarum from its related Lycium species using random amplified polymorphic DNA. Planta Med 2001; 67: 379-381

56 Watanabe A, Araki S, Kobari S, Sudo H, Tsuchida T, Uno T, Kosaka N, Shimomura K, Yamazaki $M$, Saito $K$. In vitro propagation, restriction fragment length polymorphism, and random amplified polymorphic DNA analyses of Angelica plants. Plant Cell Rep 1998; 18: 187-192

57 Liang ZT, Qin MJ, Wang ZT, Huang Y, Wang NH. Identification of Bupleurum L. plants by RAPD technology. Zhongcaoyào 2002; 33: 1117-1119

58 Zhang M, Huang HR, Liao SM, Gao JY. Cluster analysis of Dendrobium by RAPD and design of specific primer for Dendrobium candidum. Zhongguo Zhong Yao Za Zhi 2001; 26: 442-447

59 Guo BL, Wu M, Si JP, Li JS, Xiao PG. Research on DNA molecular marker of Magnolia officinalis Rehd. et Wils. RAPD study on certified species. Yao Xue Xue Bao 2001; 36: 386-389

60 Huang L, Wang M, Zhou C, Li N, He X, Yang B. Problems and solutions in the use of RAPD to the identification of the Chinese drugs "xi-xin" (Herba Asari) and its substitutes. Yao Xue Xue Bao 1998; 33: 778-784
61 Lu C, Zhang W, Peng X, Gu G, Chen M, Tang Z. Development of randomly amplified polymorphic DNA-sequence characterized amplified region marker for identification of Apocynum venetum LINN. from A. pictum SCHRENK. Biol Pharm Bull 2010; 33: 522-526

62 Li Y, Ding WL. Genetic diversity assessment of Trollius accessions in China by RAPD markers. Biochem Genet 2010; 48: 34-43

63 Dnyaneshwar W, Preeti C, Kalpana J, Bhushan P. Development and application of RAPD-SCAR marker for identification of Phyllanthus emblica L. Biol Pharm Bull 2006; 29: 2313-2316

64 Zhang R, Zhang B, Ye H. Identification of the Chinese herbs of Indigoferae L. by RAPD analysis. Hongguo Zhong Yao Za Zhi 1997; 22: 72-73

65 Cheng KT, Chang HC, Su CH, Hsu FL. Identification of dried rhizomes of Coptis species using random amplified polymorphic DNA. Bot Bull Acad Sin 1997; 38: 241-244

66 Zhang YB, Ngan FN, Wang ZT, Wang J, But PPH, Shaw PC. Differentiation of Codonopsis pilosula using random amplified polymorphic DNA. Planta Med 1999; 65: 57-60

67 Cao H, But PPH, Shaw PC. Identification of Herba Taraxaci and its adulterants in Hong Kong market by DNA fingerprinting with random primed PCR. Chin J Chin Mater Med 1997; 22: 197-200

$68 \mathrm{Cao} \mathrm{H}$, But PPH, Shaw PC. Authentication of the Chinese drug "ku-didan" (Herba Elephantopi) and its substitutes using random-primed polymerase chain reaction (PCR). Acta Pharm Sin 1996; 31: 543-553

69 Cheng JL, Huang LQ Shao AJ, Lin SF. RAPD analysis on different varieties of Rehmannia glutinosa. Zhongguo Zhongyao Zazhi 2002; 27: 505-508

70 Caetano-Anollés G, Bassam BJ, Gresshoff PM. DNA amplification fingerprinting: a strategy for genome analysis. Plant Mol Biol Rep 1991; 9: 294-307

71 Caetano-Anollés G, Bassam BJ, Gresshoff PM. DNA amplification using very short arbitrary oligonucleotide primers. Biotechnology 1991; 9: 553-557

72 Chawla HS. Introduction to Plant Biotechnology, 2nd edition. New Hampshire: Science Publishers; 2002

73 Zietkiewicz E, Rafalski A, Labuda D. Genome fingerprinting by simple sequence repeat (SSR)-anchored polymerase chain reaction amplification. Genomics 1994; 20: 176-183

74 Bornet B, Branchard M. Nonanchored inter simple sequence repeat (ISSR) markers: reproducible and specific tools for genome fingerprinting. Plant Mol Biol Rep 2001; 19: 209-215

75 Shen J, Ding XY, Ding G, Liu DY, Tang F, He J. Studies on population difference of Dendrobium officinale II establishment and optimization of the method of ISSR fingerprinting marker. Zhongguo Zhong Yao Za Zhi 2006; 31: 291-294

76 Shi HM, Wang J, Wang MY, Tu PF, Li XB. Identification of Cistanche species by chemical and inter-simple sequence repeat fingerprinting. Biol Pharm Bull 2009; 32: 142-146

77 Li K, Wu W, Zheng Y, Dai Y, Xiang L, Liao K. Genetic diversity of Fritillaria from Sichuan province based on ISSR. Zhongguo Zhong Yao Za Zhi 2009; 34: 2149-2154

78 Song Z, Li X, Wang H, Wang J. Genetic diversity and population structure of Salvia miltiorrhiza Bge in China revealed by ISSR and SRAP. Genetica 2010; $138: 241-249$

79 Hu Y, Zhang Q Xin H, Qin LP, Lu BR, Rahman K, Zheng H. Association between chemical and genetic variation of Vitex rotundifolia populations from different locations in China: its implication for quality control of medicinal plants. Biomed Chromatogr 2007; 21: 967-975

80 Kojoma M, Iida O, Makino Y, Sekita S, Satake M. DNA fingerprinting of Cannabis sativa using inter-simple sequence repeat (ISSR) amplification. Planta Med 2002; 68: 60-63

81 Xia T, Chen S, Chen S, Zhang D, Zhang D, Gao Q Ge XJ. ISSR analysis of genetic diversity of the Qinghai-Tibet plateau endemic Rhodiola chrysanthemifolia (Crassulaceae). Biochem Syst Ecol 2007; 35: 209-214

82 Wu W, Zheng YL, Chen L, Wei YM, Yang RW, Yan ZH. Evaluation of genetic relationships in the genus Houttuynia Thunb. In China based on RAPD and ISSR markers. Biochem Syst Ecol 2005; 33: 1141-1157

83 Vos $P$, Hogers R, Bleeker M, Reijans $M$, van de Lee T, Hornes $M$, Frijters A, Pot J, Peleman J, Kuiper M. AFLP: a new technique for DNA fingerprinting. Nucleic Acids Res 1995; 23: 4407-4414

84 Vos P, Kuiper M. AFLP Analysis. In: Caetano-Anollés G, Gresshoff PM, editors. DNA markers: protocols, applications,and overviews. New York: Wiley-Liss; 1997: 115-132

85 Blears M, De Grandis S, Lee H, Trevors J. Amplified fragment length polymorphism (AFLP): a review of the procedure and its applications. J Indian Microbiol Biotechnol 1998; 21: 99-114 
86 Mueller UG, Wolfenbarger L. AFLP genotyping and fingerprinting. Trends Ecol Evol 1999; 14: 389-394

87 Choi YE, Ahn CH, Kim BB, Yoon ES. Development of species specific AFLP-derived SCAR marker for authentication of Panax japonicus $C$. A. MEYER. Biol Pharm Bull 2008; 31: 135-138

88 Ha WY, Shaw PC, Liu J, Yau FC, Wang J. Authentication of Panax ginseng and Panax quinquefolius using amplified fragment length polymorphism (AFLP) and directed amplification of minisatellite region DNA (DAMD). J Agric Food Chem 2002; 50: 1871-1875

89 Zerega NJC, Mori S, Lindqvist C, Zheng $Q$ Motley TJ. Using amplified fragment length polymorphisms (AFLP) to identify black cohosh (Actaea racemosa). Econ Bot 2002; 56: 154-164

90 Passinho-Soares H, Felix D, Kaplan MA, Margis-Pinheiro M, Margis R. Authentication of medicinal plant botanical identity by amplified fragmented length polymorphism dominant DNA marker: inferences from the Plectranthus genus. Planta Med 2006; 72: 929-931

91 Loh JP, Kiew R, Kee A, Gan LH, Gan YY. Amplified fragment length polymorphism (AFLP) provides molecular markers for the identification of Caladium bicolor cultivars. Ann Bot (Lond) 1999; 84: 155-161

92 Datwyler SL, Weiblen GD. Genetic variation in hemp and marijuana (Cannabis sativa L.) according to amplified fragment length polymorphisms. J Forensic Sci 2006; 51: 371-375

93 Qi JJ, Li XE, Song J, Eneji AE, Ma X. Genetic Relationships among Rehmannia glutinosa cultivars and varieties. Planta Med 2008; 74: 1846-1852

94 Weising $K$, Nybom $H$, Wolff $K$, Meyer W. DNA Fingerprinting in Plants and Fungi. Boca Raton: CRC Press; 1995

95 Soumaya R, Dakhlaoui-Dkhil S, Salem AOM, Zehdi-Azouzi S, Rhouma A, Marrakchi $M$, Trifi $M$. Genetic diversity and phylogenic relationships in date-palms (Phoenix dactylifera L.) as assessed by random amplified microsatellite polymorphism markers (RAMPOs). Sci Hortic 2008; 117: 53-57

96 Chatti K, Saddoud O, Salhi Hannachi A, Mars M, Marrakchi M, Trifi M. Analysis of genetic diversity and relationships in a Tunisian Fig (Ficus carica) germplasm collection by random amplified microsatellite polymorphisms. J Integr Plant Biol 2007; 49: 386-391

97 Baldwin BG, Sanderson MJ, Porter JM, Wojciechowski MF, Campbell CS, Donoghue MJ. The ITS region of nuclear ribosomal DNA: a valuable source of evidence on angiosperm phylogeny. Ann Mo Bot Gard 1995; 82: 247-277

98 Alvarez I, Wendel JF. Ribosomal ITS sequences and plant phylogenetic inference. Mol Phylogenet Evol 2003; 29: 417-434

99 Chen S, Yao H, Han J, Liu C, Song J, Shi L, Zhu Y, Ma X, Gao T, Pang X, Luo $K$, Li Y, Li X, Jia X, Lin Y, Leon C. Validation of the ITS2 region as a novel DNA barcode for identifying medicinal plant species. PLoS One 2010; 5: $1-8$

100 Chiou SJ, Yen JH, Fang CL, Chen HL, Lin TY. Authentication of medicinal herbs using PCR-Amplified ITS2 with specific primers. Planta Med 2007; 73: 1421-1426

101 Ngan F, Shaw P, But P, Wang J. Molecular authentication of Panax species. Phytochemistry 1999; 50: 787-791

102 Kim OT, Bang K, In DS, Lee JW, Kim YC, Shin YS, Hyun DY, Lee SS, Cha SW, Seong NS. Molecular authentication of ginseng cultivars by comparison of internal transcribed spacer and 5.8S rDNA sequences. Plant Biotechnol Rep 2007; 1: 163-167

103 Kelly LM. Phylogenetic relationships in Asarum (Aristolochiaceae) based on morphology and ITS sequences. Am J Bot 1998; 85: 14541467

104 Liu CS, Bai GB, Yan YN. Studies on the botanical sources and DNA molecular identification of Herba Asari based on ITS sequence. Zhongguo Zhong Yao Za Zhi 2005; 30: 329-332

105 Yamaji H, Fukuda T, Yokoyama J, Pak J-H, Zhou C, Yang CS, Kondo K, Morota T, Takeda S, Sasaki H, Maki M. Reticulate evolution and phylogeography in Asarum sect. Asiasarum (Aristolochiaceae) documented in internal transcribed spacer sequences (ITS) of nuclear ribosomal DNA. Mol Phylogenet Evol 2007; 44: 863-884

106 Dong TT, Ma XQ Clarke C, Song ZH, Ji ZN, Lo CK, Tsim KW. Phylogeny of Astragalus in China: molecular evidence from the DNA sequences of 5S rRNA spacer, ITS, and 18S rRNA. J Agric Food Chem 2003; 51: 6709-6714

107 Yip PY, Kwan HS. Molecular identification of Astragalus membranaceus at the species and locality levels. J Ethnopharmacol 2006; 106: $222-229$
108 Xu H, Wang Z, Ding X, Zhou K, Xu L. Differentiation of Dendrobium species used as "Huangcao Shihu" by rDNA ITS sequence analysis. Planta Med 2006; 72: 89-92

109 Ding X, Xu L, Wang Z, Zhou K, Xu H, Wang Y. Authentication of stems of Dendrobium officinale by rDNA ITS region sequences. Planta Med 2002; 68: 191-192

110 Lau DT, Shaw PC, Wang J, But PP. Authentication of medicinal Dendrobium species by the internal transcribed spacer of ribosomal DNA. Planta Med 2001; 67: 456-460

111 Zhang YB, Wang J, Wang ZT, But PP, Shaw PC. DNA microarray for identification of the herb of Dendrobium species from Chinese medicinal formulations. Planta Med 2003; 69: 1172-1174

112 Wang CZ, Li P, Ding JY, Jin GQ Yuan CS. Identification of Fritillaria pallidiflora using diagnostic PCR and PCR-RFLP based on nuclear ribosomal DNA internal transcribed spacer sequences. Planta Med 2005; 71: 384-386

113 Yang ZY, Chao Z, Huo KK, Wu BY, Pan SL. Nuclear ribosomal DNA internal transcribed spacer 1 sequences of 4 Leonurus species. Nan Fang Yi Ke Da Xue Xue Bao 2006; 26: 1593-1595

114 Luo YM, Zhang WM, Ding XY, Shen J, Bao SL, Chu BH, Mao SG. SNP marker and allele-specific diagnostic PCR for authenticating herbs of Perilla. Acta Pharm Sin 2006; 41: 840-845

115 Lee SK, Li PT, Lau DT, Yung PP, Kong RY, Fong WF. Phylogeny of medicinal Phyllanthus species in China based on nuclear ITS and chloroplast atpB-rbcL sequences and multiplex PCR detection assay analysis. Planta Med 2006; 72: 721-726

116 Albach DC, Li HQ Zhao N, Jensen SR. Molecular systematics and phytochemistry of Rehmannia (Scrophulariaceae). Biochem Syst Ecol 2007; 35: 293-300

117 Wang H, Wang Q. Analysis of rDNA ITS sequences of Radix et Rhizoma Salviae miltiorrhizae and plants of Salvia L. Chin Tradit Herb Drugs 2005; 36: 1381-1385

118 Xue CY, Li DZ, Lu JM, Yang JB, Liu JQ. Molecular authentication of the traditional Tibetan medicinal plant Swertia mussotii. Planta Med 2006; 72: 1223-1226

119 Sahin FP, Yamashita H, Guo Y, Terasaka K, Kondo T, Yamamoto Y, Shimada H, Fujita M, Kawasaki T, Sakai E, Tanaka T, Goda Y, Mizukami H. DNA authentication of Plantago herb based on nucleotide sequences of 18S-28S rRNA internal transcribed spacer region. Biol Pharm Bull 2007; 30: 1265-1270

120 Yang ZY, Chao Z, Huo KK, Xie H, Tian ZP, Pan SL. ITS sequence analysis used for molecular identification of the Bupleurum species from northwestern China. Phytomedicine 2007; 14: 416-422

121 Xue HG, Zhou SD, He XJ, Yu Y. Molecular authentication of the traditional Chinese medicinal plant Euphorbia pekinensis. Planta Med 2006; 73: 91-93

122 Zhao KJ, Dong TT, Cui XM, Tu PF, Tsim KW. Genetic distinction of radix adenophorae from its adulterants by the DNA sequence of 5S-rRNA spacer domains. Am J Chin Med 2003; 31: 919-926

123 Carles M, Cheung MK, Moganti S, Dong TT, Tsim KW, Ip NY, Sucher NJ. A DNA microarray for the authentication of toxic traditional Chinese medicinal plants. Planta Med 2005; 71: 580-584

124 Zhao KJ, Dong TT, Tu PF, Song ZH, Lo CK, Tsim KW. Molecular genetic and chemical assessment of radix Angelica (Danggui) in China. J Agric Food Chem 2003; 51: 2576-2583

125 Dong TT, Ma XQ Clarke C, Song ZH, Ji ZN, Lo CK, Tsim KW. Phylogeny of Astragalus in China: molecular evidence from the DNA sequences of 5S rRNA spacer, ITS, and 18 S rRNA. J Agric Food Chem 2003; 51: 6709-6714

126 Ma XQ Duan JA, Zhu DY, Dong TT, Tsim KW. Species identification of Radix Astragali (Huangqi) by DNA sequence of its 5S-rRNA spacer domain. Phytochemistry 2000; 54: 363-368

127 Xia Q Zhao KJ, Huang ZG, Zhang P, Dong TT, Li SP, Tsim KW. Molecular genetic and chemical assessment of Rhizoma Curcumae in China. J Agric Food Chem 2005; 53: 6019-6026

128 Sun Y, Fung KP, Leung PC, Shi D, Shaw PC. Characterization of medicinal Epimedium species by $5 \mathrm{~S}$ rRNA gene spacer sequencing. Planta Med 2004: 70: 287-288

129 Cai ZH, Li P, Dong TT, Tsim KW. Molecular diversity of 5S-rRNA spacer domain in Fritillaria species revealed by PCR analysis. Planta Med 1999; 65: 360-364

130 Ma XQ Zhu DY, Li SP, Dong TT, Tsim KW. Authentic identification of Stigma Croci (stigma of Crocus sativus) from its adulterants by molecular genetic analysis. Planta Med 2001; 67: 183-186 
131 Zhang M, Zhang DZ, Xu XH, Zhang T, Wang ZT. 5S rRNA gene spacer sequences from Ligularia medicinal plants and the identification of HPAs-containing species. Chin J Nat Med 2005; 3: 38-40

132 Sun Y, Shaw PC, Fung KP. Molecular authentication of Radix Puerariae Lobatae and Radix Puerariae Thomsonii by ITS and 5S rRNA spacer sequencing. Biol Pharm Bull 2007; 30: 173-175

133 Chen F, Chan HY, Wong KL, Wang J, Yu MT, But PP, Shaw PC. Authentication of Saussurea lappa, an endangered medicinal material, by ITS DNA and 5S rRNA sequencing. Planta Med 2008; 74: 889-892

134 Liu YP, Cao H, Wang XT. Application of gene technology in quality control of Chinese drugs (II) - Identification of Chinese yam (Dioscorea polystachia rhizome) using DNA sequencing. Chin J Tradit Herb Drugs 2001; 32: 113-117

135 Liu YP, Cao H, Wang XT. Application of gene technology in quality control of Chinese drugs (I) - identification of Pinellia ternata species from Yuncheng, Shandong using DNA sequencing. Chin J Pharm Anal 2001; 21: 423-426

136 Zhu S, Fushimi H, Cai S, Komatsu K. Phylogenetic relationship in the genus Panax: inferred from chloroplast trnK gene and nuclear 18S rRNA gene sequences. Planta Med 2003; 69: 647-653

137 Wang CZ, Li P, Ding JY, Jin GQ Yuan CS. Identification of Fritillaria pallidiflora using diagnostic PCR and PCR-RFLP based on nuclear ribosomal DNA internal transcribed spacer sequences. Planta Med 2005; 71: 384-386

138 Lee SK, Li PT, Lau DT, Yung PP, Kong RY, Fong WF. Phylogeny of medicinal Phyllanthus species in China based on nuclear ITS and chloroplast atpB-rbcL sequences and multiplex PCR detection assay analysis. Planta Med 2006; 72: 721-726

139 Lee C, Wen J. Phylogeny of Panax using chloroplast trnC-trnD intergenic region and the utility of trnC-trnD in interspecific studies of plants. Mol Phylogenet Evol 2004; 31: 894-903

140 Albach DC, Li HQ Zhao N, Jensen SR. Molecular systematics and phyotchemistry of Rehmannia (Scrophulariaceae). Biochem Syst Ecol 2007; 35: 293-300

141 Yang M, Zhang D, Liu J, Zheng J. A molecular marker that is specific to medicinal rhubarb based on chloroplast $\operatorname{trnL} / \operatorname{trnF}$ sequences. Planta Med 2001; 67: 784-786

142 Long C, Kakiuchi N, Takahashi A, Komatsu K, Cai S, Mikage M. Phylogenetic analysis of the DNA sequence of the non-coding region of nuclear ribosomal DNA and chloroplast of Ephedra plants in China. Planta Med 2004; 70: 1080-1084

143 Xue CY, Li DZ, Lu JM, Yang JB, Liu JQ. Molecular authentication of the traditional Tibetan medicinal plant Swertia mussotii. Planta Med 2006; 72: 1223-1226

144 Hosokawa K, Minami M, Nakamura I, Hishida A, Shibata T. The sequences of the plastid gene rpl16 and the rpl16-rpl14 spacer region allow discrimination among six species of Scutellaria. J Ethnopharmacol 2005; 99: 105-108

145 Hosokawa K, Hishida A, Nakamura I, Shibata T. The sequences of the spacer region between the atpF and atpA genes in the plastid genome allows discrimination among three varieties of medicinal Angelica. Planta Med 2006: 72: 570-571

146 Gong W, Fu C-X, Luo Y-P, Qiu Y-X. Molecular identification of Sinopodophyllum hexandrum and Dysosma species using cpDNA sequences and PCR-RFLP markers. Planta Med 2006; 72: 650-652

147 Zhao YP, Qiu YX, Gong W, Li JH, Fu CX. Authentication of Actinidia macrosperma using PCR-RFLP based on trnK sequences. Bot Stud 2007; 48: $239-242$

148 Mizukami H, Okabe Y, Kohda H, Hiraoka N. Identification of the crude drug Atractylodes Rhizome (Byaku-jutsu) and Atractylodes lancea Rhizome (So-jutsu) using chloroplast trnK sequence as a molecular marker. Biol Pharm Bull 2000; 23: 589-594

149 Sasaki Y, Fushimi H, Cao H, Cai S-Q Komatsu K. Sequence analysis of Chinese and Japanese Curcuma drugs on the 18S rRNA gene and trnK gene and the application of amplification-refractory mutation system analysis for their authentication. Biol Pharm Bull 2002; 25: 15931599

150 Luo JP, Cao H, Liu YP. DNA sequencing and molecular identification of Patchouli and its substitute wrinkled gianthyssop. Yao Xue Xue Bao 2002; 37: 739-742

151 Komatsu KS, Zhu S, Fushimi H, Qui TK, Cai S, Kadota S. Phylogenetic analysis based on 18S rRNA gene and matK gene sequences of Panax vietnamensis and five related species. Planta Med 2001; 67: 461-465
152 Zhao ZL, Leng CH, Wang ZT. Identification of Dryopteris crassirhizoma and the adulterant species based on cpDNA rbcL and translated amino acid sequences. Planta Med 2007; 73: 1230-1233

153 Kondo K, Terabayashi S, Okada M, Yuan C, He S. Phylogenetic relationship of medicinally important Cnidium officinale and Japanese Apiaceae based on rbcL sequences. J Plant Res 1996; 109: 21-27

154 Lin J, Zhou X, Gao S, Wu W, Liu X, Sun X, Tang K. Authentication of Pinellia ternata and its adulterants based on PCR with specific primers. Planta Med 2006; 72: 844-847

155 Maeda M, Uryu N, Murayama N, Ishii H, Ota M, Tsuji K, Inoko H. A simple and rapid method for HLA-DP genotying by digestion of PCR-amplified DNA with allele specific restriction endonucleases. Hum Immunol 1990; 27: 111-121

156 Lum MR, Potter E, Dang T, Heber D, Hardy M, Hirsch AM. Identification of botanicals and potential contaminants through RFLP and sequencing. Planta Med 2005; 71: 841-846

157 Li X, Ding X, Chu B, Ding G, Gu S, Qian L, Wang Y, Zhou Q. Molecular authentication of Alisma orientale by PCR-RFLP and ARMS. Planta Med 2007; 73: 67-70

158 Watanabe A, Araki S, Kobari S, Sudo H, Tsuchida T, Uno T, Kosaka N, Shimomura K, Yamazaki M, Saito K. In vitro propagation, restriction fragment length polymorphism, and random amplified polymorphic DNA analyses of Angelica plants. Plant Cell Rep 1998; 18: 187-192

159 Gong W, Fu CX, Luo YP, Qiu YX. Molecular identification of Sinopodophyllum hexandrum and Dysosma species using cpDNA sequences and PCR-RFLP markers. Planta Med 2006; 72: 650-652

160 Guo Y, Tsuruga A, Yamaguchi S, Oba K, Iwai K, Sekita S, Mizukami H. Sequence analysis of chloroplast chlB gene of medicinal Ephedra species and its application to authentication of Ephedra herb. Biol Pharm Bull 2006; 29: 1207-1211

161 Wang CZ, Li P, Ding JY, Jin GQ Yuan CS. Identification of Fritillaria pallidiflora using diagnostic PCR and PCR-RFLP based on nuclear ribosomal DNA internal transcribed spacer sequences. Planta Med 2005; 71: 384-386

162 Wang CZ, Li P, Ding JY, Peng X, Yuan CS. Simultaneous identification of Bulbus Fritillariae cirrhosae using PCR-RFLP analysis. Phytomedicine 2007; 14: 628-632

163 Lee JH, Lee JW, Sung JS, Bang KH, Moon SG. Molecular authentication of 21 Korean Artemisia species (Compositae) by polymerase chain reaction-restriction fragment length polymorphism based on trnL-F region of chloroplast DNA. Biol Pharm Bull 2009; 32: 1912-1916

164 Diao Y, Lin XM, Liao CL, Tang CZ, Chen ZJ, Hu ZL. Authentication of Panax ginseng from its adulterants by PCR-RFLP and ARMS. Planta Med 2009; 75: 557-560

165 Do KR, Hwang WJ, Lyu YS, An NH, Kim HM. Molecular authentication of Panax ginseng species by RAPD analysis and PCR-RFLP. Biol Pharm Bull 2001; 24: 872-875

166 Lu KT, Lee HC, Liu FS, Lo CF, Lin JH. Identification of ginseng radix in Chinese medicine preparations by nested PCR-DNA sequencing method and nested PCR-restriction fragment length polymorphism. J Food Drug Anal 2010; 18: 58-63

167 Um JY, Chung HS, Kim MS, Na HJ, Kwon HJ, Kim JJ, Lee KM, Lee SJ, Lim JP, Do KR, Hwang WJ, Lyu YS, An NH, Kim HM. Molecular authentication of Panax ginseng species by RAPD analysis and PCR-RFLP. Biol Pharm Bull 2001; 24: 872-875

168 Zhao YP, Qiu YX, Gong W, Li JH, Fu CX. Authentication of Actinidia macrosperma using PCR-RFLP based on trnK sequences. Bot Stud 2007; 48: $239-242$

169 Mizukami H, Okabe Y, Kohda H, Hiraoka N. Identification of the crude drug Atractylodes rhizome (Byaku-jutsu) and Atractylodes lancea rhizome (So-jutsu) using chloroplast TrnK sequence as a molecular marker. Biol Pharm Bull 2000; 23: 589-594

170 Mizukami H, Ohbayashi K, Umetsu K, Hiraoka N. Restriction fragment length polymorphism of medicinal plants and crude drugs. II. Analysis of Glehnia littoralis of different geographical origin. Biol Pharm Bull 1993; 16: 611-612

171 Lu KT, Lee HC, Liu FS, Lo CF, Lin JH. Discriminating Astragali Radix from Hedysarum Radix in Chinese Medicine Preparations Using Nested PCR and DNA Sequencing Methods. J Food Drug Anal 2009; 17: 380-385

172 Zhang T, Xu LS, Wang ZT, Zhou KY, Zhang N, Shi YF. Molecular identification of medicinal plants: Dendrobium chrysanthum, Dendrobium fimbriatum and their morphologically allied species by PCR-RFLP analyses. Yao Xue Xue Bao 2005; 40: 728-733 
173 Mizukami H, Ohbayashi K, Kitamura Y, Ikenaga T. Restriction fragment length polymorphisms (RFLPs) of medicinal plants and crude drugs. I. RFLP probes allow clear identification of Duboisia interspecific hybrid genotypes in both fresh and dried tissues. Biol Pharm Bull 1993; 16: 388-390

174 Fu RZ, Wang J, Zhang YB, Wang ZT, But PP, Li N, Shaw PC. Differentiation of medicinal Codonopsis species from adulterants by polymerase chain reaction-restriction fragment length polymorphism. Planta Med 1999; 65: 648-650

175 Desmarais E, Lanneluc I, Lagnel J. Direct amplification of length polymorphisms (DALP), or how to get and characterize new genetic markers in many species. Nucleic Acids Res 1998; 26: 1458-1465

176 Ma YS, Yu H, Li YY, Yan H, Cheng X. A study of genetic structure of Stephania yunnanensis (Menispermaceae) by DALP. Biochem Genet 2008; 46: 227-240

177 Ha WY, Yau FC, But PP, Wang J, Shaw PC. Direct amplification of length polymorphism analysis differentiates Panax ginseng from $P$. quinquefolius. Planta Med 2001; 67: 587-589

178 Newton CR, Graham A, Heptinstall LE, Powell SJ, Summers C, Kalsheker $N$, Smith JC, Markham AF. Analysis of any point mutation in DNA. The amplification refractory mutation system (ARMS). Nucleic Acids Res 1989; 17: 2503-2516

179 Li X, Ding X, Chu B, Ding G, Gu S, Qian L, Wang Y, Zhou Q. Molecular authentication of Alisma orientale by PCR-RFLP and ARMS. Planta Med 2007: 73: $67-70$

180 Zhu S, Fushimi H, Cai S, Komatsu K. Species identification from Ginseng drugs by multiplex amplification refractory mutation system (MARMS). Planta Med 2004; 70: 189-192

181 Diao Y, Lin XM, Liao CL, Tang CZ, Chen ZJ, Hu ZL. Authentication of Panax ginseng from its Adulterants by PCR-RFLP and ARMS. Planta Med 2009; 75: 557-560

182 Yang DY, Fushimi H, Cai SQ Komatsu K. Polymerase chain reactionrestriction fragment length polymorphism (PCR-RFLP) and amplification refractory mutation system (ARMS) analyses of medicinally used Rheum species and their application for identification of Rhei Rhizoma. Biol Pharm Bull 2004; 27: 661-669

183 Ding G, Zhang D, Feng Z, Fan W, Ding X, Li X. SNP, ARMS and SSH authentication of medicinal Dendrobium officinale Kimura et Migo and application for identification of Fengdou drugs. Biol Pharm Bull 2008; 31: 553-557

184 Qian L, Ding G, Zhou Q Feng ZY, Ding XY, Gu S, Wang Y, Li XX, Chu BH. Molecular authentication of Dendrobium loddigesii Rolfe by amplification refractory mutation system (ARMS). Planta Med 2008; 74: 470473

185 Sasaki Y, Fushimi H, Cao H, Cai SQ Komatsu K. Sequence analysis of Chinese and Japanese Curcuma drugs on the 18S rRNA gene and trnK gene and the application of amplification-refractory mutation system analysis for their authentication. Biol Pharm Bull 2002; 25: 1593 1599

186 Semagn K, Bjørnstad A, Ndjiondjop MN. An overview of molecular marker methods for plants. African J Biotechnol 2006; 5: 2540-2568

187 McDermott JM, Brandle U, Dutly F, Haemmerli UA, Keller S, Muller KE, Wolf MS. Genetic variation in powdery mildew of barley: development of RAPD, SCAR and VNTR markers. Phytopathology 1994; 4: 1316-1321

188 Albani MC, Battey NH, Wilkinson MJ. The development of ISSR derived SCAR markers around the saesonal flowering locus (SFL) in Fragaria vesca. Theor Appl Genet 2004; 109: 571-579

189 Paran I, Kesseli R, Michelmore R. Identification of restrictionfragmentlength-polymorphism and random amplified polymorphic DNA markers linked to downy mildew resistance genes in lettuce, using near isogenic lines. Genome 1991; 34: 1021-1027

190 Wang J, Ha WY, Ngan FN, But PP, Shaw PC. Application of sequence characterized amplified region (SCAR) analysis to authenticate Panax species and their adulterants. Planta Med 2001; 67: 781-783

191 Choi YE, Ahn CH, Kim BB, Yoon ES. Development of species specific AFLP-derived SCAR marker for authentication of Panax japonicus $C$. A. MEYER. Biol Pharm Bull 2008; 31: 135-138

192 Lee MY, Doh EJ, Park CH, Kim YH, Kim ES, Ko BS, Oh SE. Development of SCAR marker for discrimination of Artemisia princeps and A. argyi from other Artemisia herbs. Biol Pharm Bull 2006; 29: 629-633

193 Dnyaneshwar W, Preeti C, Kalpana J, Bhushan P. Development and application of RAPD-SCAR marker for identification of Phyllanthus emblica LINN. Biol Pharm Bull 2006; 29: 2313-2316
194 Theerakulpisut P, Kanawapee N, Maensiri D, Bunnag S, Chantaranothai $P$. Development of species-specific SCAR markers for identification of three medicinal species of Phyllanthus. J Syst Evol 2008; 46: 614-621

195 Devaiah KM, Venkatasubramanian P. Development of SCAR marker for authentication of Pueraria tuberosa (Roxb. ex. Willd.) DC. Curr Sci 2008; 94: 1306-1308

196 Ye Q Qiu YX, Quo YQ, Chen JX, Yang SZ, Zhao MS, Fu CX. Species-specific SCAR markers for authentication of Sinocalycanthus chinensis J Zhejiang Univ Sci B 2006; 7: 868-872

197 Devaiah KM, Venkatasubramanian P. Genetic characterization and authentication of Embelia ribes using RAPD-PCR and SCAR marker. Planta Med 2008; 74: 194-196

198 Sze SCW, Song JX, Wong RNS, Feng YB, Ng TB, Tong Y, Zhang KYB. Application of SCAR (sequence characterized amplified region) analysis to authenticate Lycium barbarum (wolfberry) and its adulterants. Biotechnol Appl Biochem 2008; 51: 15-21

199 Litt M, Luty JA. A hypervariable microsatellite revealed by in vitro amplification of a dinucleotide repeat within the cardiac muscle actin gene. Am J Hum Genet 1989; 44: 397-401

200 Tautz D. Hypervariablity of simple sequences as a general source of polymorphic DNA markers. Nucleic Acids Res 1989; 17: 6463-6471

201 Gupta PK, Balyan HS, Sharma PC, Ramesh B. Microsatellites in plants: a new class of molecular markers. Curr Sci 1996; 70: 45-54

$202 \mathrm{Kim}$ J, Jo BH, Lee KL, Yoon ES, Ryu GH, Chung KW. Identification of new microsatellite markers in Panax ginseng. Mol Cells 2007; 24: 60-68

203 Jo BH, Suh DS, Cho EM, Kim J, Ryu GH, Chung KW. Characterization of polymorphic microsatellite loci in cultivated and wild Panax ginseng. Genes Genomics 2009; 31: 119-127

$204 \mathrm{Kim}$ J, Chung KW. Isolation of new microsatellite-containing sequences in Acanthopanax senticosus. J Plant Biol 2007; 50: 557-561

205 Fan WJ, Luo YM, Li XX, Gu S, Xie ML, He J, Cai WT, Ding XY. Development of microsatellite markers in Dendrobium fimbriatum Hook, an endangered Chinese endemic herb. Mol Ecol Res 2009; 9: 373-375

206 Kumar J, Verma V, Shahi AK, Qazi GN, Balyan HS. Development of simple sequence repeat markers in Cymbopogon species. Planta Med 2007; 73: 262-266

207 Chun S, Jian-He W, Shi-Lin C, Huai-Qiong C, Cheng-Min Y. Development of genomic SSR and potential EST-SSR markers in Bupleurum chinense DC. African J Biotechnol 2009; 8: 6233-6240

208 Boqian Y, Jing W, Guopei C, Ting W. Isolation and characterization of polymorphic microsatellite loci in a traditional Chinese medicinal plant, Schisandra sphenanthera. Conserv Genet 2009; 10: 615-617

209 Vos P, Hogers R, Bleeker M, Reijans M, Van de Lee T, Hornes M, Frijters A, Pot J, Peleman J, Kuiper M, Zabeau M. AFLE a new technique for DNA fingerprinting. Nucleic Acids Res 1995; 23: 4407-4441

210 Paglia GE, Olivieri AM, Morgante M. Towards second-generation STS (sequence-tagged sites) linkage maps in conifers, a genetic map of Norway spruce (Picea abies K.). Mol Gen Genet 1998; 258: 466-478

211 Karp A, Edwards KJ. DNA markers, a global overview. In: CaetanoAnollds G, Gresshoff PM, editors. DNA Markers, Protocols, Applications, and Overviews. New York: Wiley-Liss; 1997

212 Molina C, Kahl G. Genomics of two banana pathogens, genetic diversity, diagnostics, and phylogeny of Mycosphaerella fijiensis and M. musicola. In: Jain SM, editor. Banana Improvement, Cellular and Molecular Biology, and Induced Mutations. Vienna: FAO/IAEA; 2002

213 Winter E, Pfaff T, Udupa SM, Hiittel B, Sharma PC, Sahi S, Arreguin-Espinoza R, Weigand F, Muehlbauer FJ, Kah G. Characterization and mapping of sequence-tagged microsatellite sites in the chickpea (Cicer arietinum L.) genome. Mol Gen Genet 1999; 262: 90-101

214 Witsenboer H, Vogel J, Michelmore RW. Identification, genetic localization, and allelic diversity of selectively amplified polymorphic loci in lettuce and wild relatives (Lactuca spp.). Genome 1997; 40: 923-936

215 Sarwat M, Das S, Srivastava PS. Analysis of genetic diversity through AFLP, SAMPL, ISSR and RAPD markers in Tribulus terrestris, a medicinal herb. Plant Cell Rep 2008; 27: 519-528

216 Heath DD, Iwama GK, Devlin RH. PCR primed with VNTR core sequences yields species specific patterns and hypervariable probes. Nucleic Acids Res 1993; 21: 5782-5785

217 Somers DJ, Demmon G. Identification of repetitive, genome-specific probes in crucifer oilseed species. Genome 2002; 45: 485-492

218 Silva LM, Montes de Oca H, Diniz CR, Fortes-Dias CL. Fingerprinting of cell lines by directed amplification of minisatellite-region DNA (DAMD). Braz J Med Biol Res 2001; 34: 1405-1410 
219 Zhou Z, Bebeli PJ, Somers DJ, Gustafson JP. Direct amplification of minisatellite-region DNA with VNTR core sequences in the genus Oryza. Theor Appl Genet 1997; 95: 942-949

220 Ha WY, Shaw PC, Liu J, Yau F, Wang J. Authentication of Panax ginseng and Panax quinquefolius using amplified fragment length polymorphism (AFLP) and directed amplification of minisatellite region DNA (DAMD). J Agric Food Chem 2002; 50: 1871-1875

221 Ince AG, Karaca M, Onus AN. Development and utilization of diagnostic DAMD-PCR markers for Capsicum accessions. Genet Resour Crop Evol 2009; 56: 211-221

222 Karaca M, Ince AG, Tugrul S, Turgut K, Onus AN. PCR-RFLP and DAMD-PCR genotyping for Salvia species. J Sci Food Agric 2008; 88: 2508-2516

223 Bhattacharya E, Dandin SB, Ranade SA. Single primer amplification reaction methods reveal exotic and indigenous mulberry varieties are similarly diverse. J Biosci 2005; 30: 669-677

224 Chavan P, Joshi K, Patwardhan B. DNA microarrays in herbal drug research. Evid Based Complement Alternat Med 2006; 3: 447-457

225 Gebauer M. Microarray applications: emerging technologies and perspectives. Drug Discov Today 2004; 9: 915-917

226 Debouck C, Goodfellow PN. DNA microarrays in drug discovery and development. Nat Genet 1999; 21: 48-50

227 Trau D, Lee TM, Lao AI, Lenigk R, Hsing IM, Ip NY. Genotyping on a complementary metal oxide semiconductor silicon polymerase chain reaction chip with integrated DNA microarray. Anal Chem 2002; 74 : 3168-3173

228 Tsoi PY, Wu HS, Wong MS, Chen SL, Fong WF, Xiao PG, Yang MS. Genotyping and species identification of Fritillaria by DNA chip technology. Acta Pharm Sin 2003; 4: 185-190

229 Li T, Wang J, Lu Z. Accurate identification of closely related Dendrobium species with multiple species-specific gDNA probes. J Biochem Biophys Methods 2005; 62: 111-123

230 Zhang YB, Wang J, Wang ZT, But PP, Shaw PC. DNA microarray for identification of the herb of Dendrobium species from Chinese medicinal formulations. Planta Med 2003; 69: 1172-1174

231 Lin WY, Chen LR, Lin TY. Rapid authentication of Bupleurum species using an array of immobilized sequence-specific oligonucleotide probes. Planta Med 2008; 74: 464-469
232 Qin J, Leung FC, Fung Y, Zhu D, Lin B. Rapid authentication of ginseng species using microchip electrophoresis with laser-induced fluorescence detection. Anal Bioanal Chem 2005; 381: 812-819

233 Carles M, Cheung MK, Moganti S, Dong TT, Tsim KW, Ip NY, Sucher NJ. A DNA microarray for the authentication of toxic traditional Chinese medicinal plants. Planta Med 2005; 71: 580-584

234 Pastinen T, Partanen J, Syvanen AC. Multiplex, fluorescent, solid-phase minisequencing for efficient screening of DNA sequence variation. Clin Chem 1996; 42: 1391-1397

235 Cai H, White PS, Torney D, Deshpande A, Wang Z, Keller RA, Marrone B, Nolan JP. Flow cytometry-based minisequencing: a new platform for high-throughput single-nucleotide polymorphism scoring. Genomics 2000; 66: 135-143

236 Pastinen T, Raitio M, Lindroos K, Tainola P, Peltonen L, Syvänen AC. A system for specific, high-throughput genotyping by allele-specific primer extension on microarrays. Genome Res 2000; 10: 1031-1042

237 Lowe CR. Nanobiotechnology: the fabrication and applications of chemical and biological nanostructures. Curr Opin Struct Biol 2000; 10: $428-434$

238 Fortina P, Kricka LJ, Surrey S, Grodzinski P. Nanobiotechnology: the promise and reality of new approaches to molecular recognition. Trends Biotechnol 2005; 23: 168-173

239 Pirrung MC, Connors RV, Odenbaugh AL, Montague-Smith MP, Walcott $N G$, Tollett JJ. The arrayed primer extension method for DNA microchip analysis. Molecular computation of satisfaction problems. J Am Chem Soc 2000; 122 : 1873-1882

240 Kurg A, Tõnisson N, Georgiou I, Shumaker J, Tollett J, Metspalu A. Arrayed primer extension: solid-phase four-color DNA resequencing and mutation detection technology. Genet Test 2000; 4: 1-7

241 Grossman PD, Bloch W, Brinson E, Chang CC, Eggerding FA, Fung S, Iovannisci DM, Woo $S$, Winn-Deen ES, Iovannisci DA. High-density multiplex detection of nucleic acid sequences: oligonucleotide ligation assay and sequence-coded separation. Nucleic Acids Res 1994; 22: 4527-4534

242 Cimino MT. Successful isolation and PCR amplification of DNA from National Institute of Standards and Technology herbal dietary supplement standard reference material powders and extracts. Planta Med 2010; 76: 495-497 